\title{
Pseudoscorpions (Arachnida) collected from the heaps with decomposing material in Slovakia
}

\author{
Andrea KAŇUCHOVÁ, Jana CHRISTOPHORYOVÁ and Katarína KRAJČOVIČOVÁ \\ Department of Zoology, Faculty of Natural Sciences, Comenius University, Mlynská dolina B-1, Ilkovičova 6, SK-842 \\ 15 Bratislava, Slovakia; e-mail to corresponding author: christophoryova@gmail.com
}

\begin{abstract}
The first detailed survey of pseudoscorpions living in the heaps with decomposing material (compost heaps, manures) is presented. The research was performed on samples from 33 localities in Slovakia during the years 20122014. A total of 1118 pseudoscorpions of ten species in four families was examined during the study. The most abundant family was Chernetidae, whereas the lowest species and specimen numbers were recorded for the families Neobisiidae and Cheliferidae. Chernetid pseudoscorpions of the genus Lamprochernes Tömösváry, 1882 and of the species Pselaphochernes scorpioides (Hermann, 1804) were the most abundant. These are typical inhabitants of heaps with decomposing material, in which all their developmental stages, even females with eggs (in the case of P. scorpioides), can be found. Only one specimen each of Dactylochelifer latreillii (Leach, 1817) and Dinocheirus panzeri (C.L. Koch, 1831) was found. From a faunistic point of view, the first confirmed Slovakian record of the rare species Chthonius ressli Beier, 1956 is notable.
\end{abstract}

Key words: compost heaps, decomposing material, Central Europe

\section{INTRODUCTION}

Due to their microclimate and organic richness, compost heaps provide a favourable environment for the development of various organisms. A large number of decomposers, such as springtails and mites, inhabit compost, in which they play an important role in humification. They, in turn, serve as food for predators, including pseudoscorpions.

Despite this, pseudoscorpions living in compost or other decaying material have been studied sporadically in Slovakia. Verner (1971) mentioned, in general, that the species Lamprochernes nodosus (Schrank, 1803) lived in decaying plant material. Christophoryová (2009) found two males of Lamprochernes chyzeri (Tömösváry, 1882) in manure at Šurice in the Cerová vrchovina Highlands. The first record of Chthonius hungaricus Mahnert, 1981 in Slovakia referred to decaying plant material and manure at the same locality (Christophoryová 2009). Three specimens of Atemnus politus (Simon, 1878) and 26 of L. nodosus were collected in compost heaps and rotten hay in the Burda Mts (Christophoryová et al. 2014).

In other European countries, some authors provided general information about pseudoscorpion occurrence in compost or manure heaps. Beier (1963) mentioned in his identification key that compost heaps were a typical habitat for the species L. nodosus and Pselaphochernes scorpioides (Hermann, 1804). Ressl (1970) and Jędryczkowski (1985) mentioned, that among other habitats, P. scorpioides occurred in compost. Legg \& Jones (1988) stated that compost was a typical habitat for the species Lamprochernes savignyi (Simon, 1881), L. nodosus, L. chyzeri and P. scorpioides. Other records of P. scorpioides in compost came from distant countries, including Spain (Beier 1955), the Azores (Beier 1961) and Crete (Beier 1966). Ressl \& Beier (1958) recorded pseudoscorpion species in compost in Lower Austria. Pselaphochernes scorpioides was recorded in garden compost heaps located on field edges and containing mostly potato waste. The species Chthonius fuscimanus Simon, 1900, Neobisium sylvaticum (C.L. Koch, 1835), N. carcinoides (Hermann, 1804), Allochernes 
wideri (C.L. Koch, 1843), Dactylochelifer latreillii (Leach, 1817) and P. scorpioides were found in compost heaps located near streams and forest edges. These contained mostly plant material, such as leaves, moss or hay. Also, Chthonius tetrachelatus (Preyssler, 1970), C. fuscimanus, C. pusillus Beier, 1947 and N. carcinoides were collected in compost containing mostly old plant waste, dry leaves, hay, moss and old wood (Ressl \& Beier 1958). Drogla \& Lippold (2004) recorded occasional occurrences of C. tetrachelatus, N. sylvaticum, D. latreillii and L. chyzeri in compost heaps of West Germany. However, Allochernes powelli (Kew, 1916), D. panzeri (C.L. Koch, 1837), L. nodosus and P. scorpioides were well represented (Drogla \& Lippold 2004). Štáhlavský (2006) found one female of $P$. scorpioides under a piece of wood in compost in Podyjí National Park in the Czech Republic. Št'áhlavský \& Chytil (2013) reported finding of a male of $D$. panzeri in compost at Valtice, Czech Republic.

The aim of the present paper is to extend the knowledge on the pseudoscorpion fauna from the heaps with decomposing material in Slovakia.

\section{MATERIAL AND METHODS}

The studied material was collected by following collectors: Jana Christophoryová, Peter Fend’a, Daniel Grul'a, Milada Holecová, Kamila Hrúzová, Andrea Kaňuchová, Andrej Krajča, Katarína Krajčovičová, Jasna Kraljik, Barbora Mangová, Andrej Mock, Ján Rudy, Eduard Stloukal, Viera Stloukalová, Anna Šestáková and Lucia Štasselová. The material from 33 localities in Slovakia was investigated during the years 2012-2014 (Fig. 1, Table 1). Each sample was collected from heap formed by humans. The samples of heaps with decomposing material (Figs $3 \& 5$ ) were collected by hand and transported in polyethylene bags. The samples were taken from the deeper parts of the heaps with decomposing material. Each sample volume was approximately $6 \mathrm{dm}^{3}$. The number of samples was from 1 to 8 per each locality (Table 1 ).

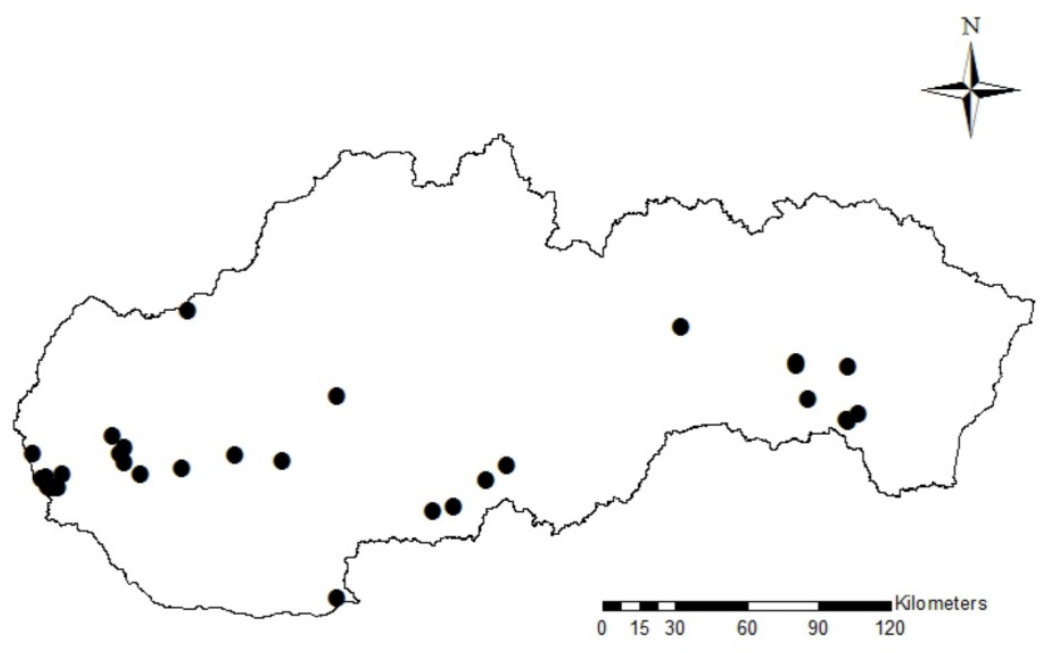

Fig. 1. Location of sampling areas in Slovakia.

Heaps with decomposing material were divided into six categories according to environmental type and their composition (Table 1). Category A included compost heaps in gardens situated close to houses in rural landscapes. These heaps consisted of grass, kitchen and plant waste, and animal waste (excrement, feathers, eggshells). Category B included heaps with decomposing material in allotment gardens situated mainly in villages and community gardens. These consisted mainly of plant material, such as grass, leaves, vegetables waste and 
pieces of bark. Category $\mathrm{C}$ included heaps with decomposing material containing silage material and situated in agricultural areas. Category D included compost heaps situated in botanical gardens or an arboretum, which were made up of typical garden waste, such as lops, woody parts and decaying leaves. Category E covered heaps with decomposing material situated in forest environment and park, containing mainly leaves, leaf litter and grass. Category $\mathrm{F}$ included manure heaps and cow dung from a cow shed.

Table 1. List of localities. N - North latitude, E - East longitude, NS - number of samples. For categories A-F see Material and Methods.

\begin{tabular}{|c|c|c|c|c|c|c|}
\hline No & Locality & $\mathrm{N}$ & $\mathrm{E}$ & $\mathrm{m}$ a.s.1 & Environment (Category) & NS \\
\hline 1 & Bratislava, Botanical Garden & 48.14544444 & 17.07254167 & 143 & botanical garden (D) & 2 \\
\hline 2 & Bratislava, Botanical Garden & 48.14745 & 17.07405 & 152 & botanical garden (D) & 4 \\
\hline 3 & Bratislava, Dúbravka & 48.183921 & 17.048366 & 236 & allotment garden (B) & 1 \\
\hline 4 & Bratislava, Fialkové údolie & 48.14344444 & 17.09113889 & 202 & house garden $(\mathrm{A})$ & 3 \\
\hline 5 & Bratislava, Jezuitské lesy & 48.176225 & 17.02437778 & 315 & allotment garden (B) & 1 \\
\hline 6 & Bratislava, Prírodovedecká fakulta & 48.14902222 & 17.06854722 & 159 & forest $(\mathrm{E})$ & 1 \\
\hline 7 & Bratislava, Rača - Krasňany & 48.196612 & 17.142575 & 144 & community garden (B) & 1 \\
\hline 8 & Bratislava, Sasinková & 48.149673 & 17.122279 & 142 & community garden (B) & 1 \\
\hline 9 & Budmerice & 48.36219444 & 17.39618056 & 210 & park around manor house $(\mathrm{E})$ & 1 \\
\hline 10 & Čataj & 48.26537222 & 17.48060278 & 132 & house garden $(\mathrm{A})$ & 1 \\
\hline 11 & Čebovce & 48.17873611 & 19.22808889 & 227 & house garden (A) & 1 \\
\hline 12 & Devínske jazero & 48.26222222 & 16.96444444 & 140 & house garden (A) & 8 \\
\hline 13 & Jarná & 48.32151111 & 17.46876667 & 148 & agricultural area $(\mathrm{C})$ & 1 \\
\hline 14 & Kalša & 48.61152778 & 21.53631111 & 196 & former agricultural cooperative (C) & 1 \\
\hline 15 & Kalša & 48.61152778 & 21.5363111 & 196 & house garden $(\mathrm{A})$ & 1 \\
\hline 16 & Kalša & 48.61368 & 21.52284 & 203 & garden in village (B) & 1 \\
\hline 17 & Kamenica nad Hronom & 47.82870278 & 18.73423611 & 108 & house garden (A) & 1 \\
\hline 18 & Kaplna & 48.29765278 & 17.45408611 & 152 & house garden (A) & 2 \\
\hline 19 & Kl'ak & 48.58316944 & 18.64434722 & 609 & house garden $(\mathrm{A})$ & 2 \\
\hline 20 & Košice & 48.68464444 & 21.298183 & 210 & allotment garden (B) & 1 \\
\hline 21 & L'uboreč & 48.312675 & 19.51868333 & 276 & house garden $(\mathrm{A})$ & 1 \\
\hline 22 & Nitra, Zobor & 48.33425278 & 18.09750278 & 259 & house garden (A) & 1 \\
\hline 23 & Plevovec, Kopanice u Zlatých & 48.85801667 & 17.75992778 & 380 & house garden (A) & 2 \\
\hline 24 & Pusté Ul'any & 48.22500556 & 17.57988611 & 120 & grove $(\mathrm{E})$ & 1 \\
\hline 25 & Sokol' & 48.81233 & 21.22676 & 250 & garden in village (B) & 1 \\
\hline 26 & Sokol' & 48.81575 & 21.52284 & 290 & allotment garden (B) & 1 \\
\hline 27 & Sokol'-Uhrinč & 48.82027 & 21.22114 & 247 & allotment garden (B) & 1 \\
\hline 28 & Spišská Nová Ves & 48.93335556 & 20.55928889 & 469 & forest $(\mathrm{E})$ & 1 \\
\hline 29 & Šoporňa & 48.26457222 & 17.80788611 & 129 & house garden (A) & 1 \\
\hline 30 & Tesárske Mlyňany & 48.32259167 & 18.36371389 & 170 & arboretum (D) & 1 \\
\hline 31 & Tomášovce & 48.373825 & 19.62281111 & 199 & garden in village (B) & 1 \\
\hline 32 & Vel'ký Krtíš & 48.20629444 & 19.34442778 & 192 & restaurant garden $(\mathrm{A})$ & 1 \\
\hline 33 & Zemplínska Teplica & 48.63672 & 21.58542 & 204 & cow shed $(\mathrm{F})$ & 1 \\
\hline
\end{tabular}

Pseudoscorpions were heat-extracted using Tullgren funnels. Some of the specimens obtained were studied as temporary slide mounts using lactic acid and then returned to $70 \%$ ethanol, but most were studied as permanent slide mounts, made using Swann's fluid. All specimens were identified using the key in Christophoryová et al. (2011c). The identification of Chthonius ressli Beier, 1956 was made by comparison with the descriptions of Beier (1956, 1963) and Judson (1990). The identifications of C. ressli and Chthonius tetrachelatus (Preyssler, 1790) were checked and confirmed by Dr Giulio Gardini. Nomenclature for all taxa follows Harvey (2013). The micrograph of $P$. scorpioides (Fig. 4) was made using EOS Utility software and a digital camera (Canon EOS 1100D) connected to a Zeiss Stemi 2000-C stereomicroscope. The material is deposited in the zoological collections of Comenius University, Bratislava. 


\section{RESULTS}

During the study, 1118 specimens of 10 taxa from four families were identified from the studied localities (Table 2). The specimens of the genus Lamprochernes Tömösváry, 1882 were not identified to species level, due to an ongoing taxonomic revision. The family Chernetidae was the most abundant, with almost 1000 collected specimens in five taxa. The lowest number of species and specimens was recorded for Neobisiidae and Cheliferidae (Table 2). Pseudoscorpions of the genus Lamprochernes and the species $P$. scorpioides were the most abundant. These two taxa also occurred at the most localities (Table 2). Only one specimen each of the species D. latreillii and D. panzeri was found. The occurrence of the rare species Chthonius ressli Beier, 1956 in Slovakia was confirmed. The list of the collected taxa is given below with locality code, date and number of each developmental stage ( $\odot$ : female, $\hat{\sigma}$ : male, Tn: tritonymph, Dn: deutonymph, Pn: protonymph, A: adult of undetermined sex).

Table 2. Number of specimens of pseudoscorpions in heaps with decomposing material in Slovakia. Cr - Chthonius ressli, Cf - C. fuscimanus, Ct - C. tetrachelatus, $N c-N e o b i s i u m$ carcinoides, Dl - Dactylochelifer latreillii, Ch Chernes hahnii, Dp - Dinocheirus panzeri, Aw - Allochernes wideri, Lsp - Lamprochernes spp., Ps Pselaphochernes scorpioides.

\begin{tabular}{|c|c|c|c|c|c|c|c|c|c|c|c|c|}
\hline No & Locality & $\mathrm{Cr}$ & $C f$ & $C t$ & $N c$ & $D l$ & $\mathrm{Ch}$ & $D p$ & $A w$ & $L \mathrm{sp}$ & Ps & $\Sigma$ \\
\hline 1 & Bratislava, Botanical Garden & & & & & & & 1 & & 34 & 6 & 41 \\
\hline 2 & Bratislava, Botanical Garden & & & & & & & & & 22 & 14 & 36 \\
\hline 3 & Bratislava, Dúbravka & & & 1 & & & & & & & 17 & 18 \\
\hline 4 & Bratislava, Fialkové údolie & & & 5 & & & & & & 10 & 96 & 111 \\
\hline 5 & Bratislava, Jezuitské lesy & & 2 & & & & & & & 4 & 4 & 10 \\
\hline 6 & Bratislava, Prírodovedecká fakulta & & & & & & & & & 1 & & 1 \\
\hline 7 & Bratislava, Rača - Krasňany & & & & & & 1 & & & 1 & & 2 \\
\hline 8 & Bratislava, Sasinková & & & 9 & & & & & & & & 9 \\
\hline 9 & Budmerice & & & 3 & & & & & & 1 & 8 & 12 \\
\hline 10 & Čataj & & & & & & & & & 13 & & 13 \\
\hline 11 & Čebovce & & & & & & & & & 1 & & 1 \\
\hline 12 & Devínske jazero & & & 1 & & & 4 & & & 275 & 4 & 284 \\
\hline 13 & Jarná & & & 4 & & & & & & 10 & & 14 \\
\hline 14 & Kalša & & & 4 & & & & & & 28 & & 32 \\
\hline 15 & Kalša & & & & & & & & & & 6 & 6 \\
\hline 16 & Kalša & & & & & & & & & & 26 & 26 \\
\hline 17 & Kamenica nad Hronom & & & & & & & & & 54 & & 54 \\
\hline 18 & Kaplna & & & & & & & & & 30 & 29 & 59 \\
\hline 19 & Klak & & & & & & & & & 1 & 6 & 7 \\
\hline 20 & Košice & & & & & & & & & 8 & 15 & 23 \\
\hline 21 & Luboreč & & & & & & & & 1 & & 2 & 3 \\
\hline 22 & Nitra, Zobor & & & & & & & & & 65 & & 65 \\
\hline 23 & Plevovec, Kopanice u Zlatých & & & 20 & 6 & & & & 5 & 6 & 57 & 94 \\
\hline 24 & Pusté Ulany & 49 & & 19 & & & & & 6 & 1 & & 75 \\
\hline 25 & Sokol' & & & & & & & & & & 1 & 1 \\
\hline 26 & Sokol' & & & & 2 & & & & & & & 2 \\
\hline 27 & Sokol'-Uhrinč & & & & & & & & & & 1 & 1 \\
\hline 28 & Spišská Nová Ves & & & & & & & & & 10 & 5 & 15 \\
\hline 29 & Šoporn̆a & & & & & & & & 2 & & & 2 \\
\hline 30 & Tesárske Mlyňany & & & & & & & & & 1 & & 1 \\
\hline 31 & Tomášovce & & & 1 & & 1 & & & & 1 & 1 & 4 \\
\hline 32 & Vel'ký Krtíš & & & & & & & & & 94 & & 94 \\
\hline 33 & Zemplínska Teplica & & & & & & & & & 2 & & 2 \\
\hline & $\sum$ & 49 & 2 & 67 & 8 & 1 & 5 & 1 & 14 & 673 & 298 & 1118 \\
\hline
\end{tabular}


Family Chthoniidae Daday, 1888

Chthonius (Chthonius) ressli Beier, 1956

24: 22 Sep 2013, 10 우, 10 ถึఠึ, 2 Dn, 27 Tn.

Chthonius (Ephippiochthonius) fuscimanus Simon, 1900

5: 5 Oct 2013, 1 ㅇ, 1 Љ

\section{Chthonius (Ephippiochthonius) tetrachelatus (Preyssler, 1790)}

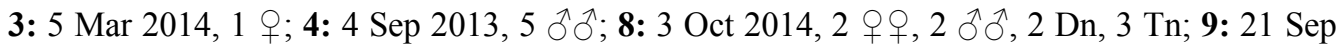

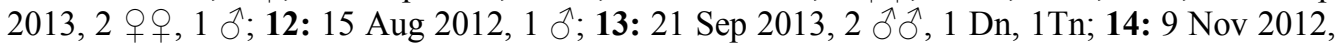

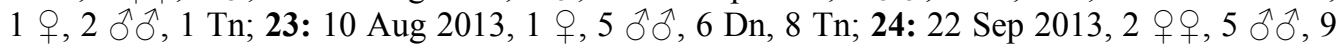
Dn, 3 Tn; 31: 22 Sep 2013, 1 ㅇ.

Family Neobisiidae Chamberlin, 1930

Neobisium (Neobisium) carcinoides (Hermann, 1804)

23: 10 Aug 2013, 4 Pn, 2 Dn; 26: 25 Oct 2013, 1 †, 1 ふ..

Family Cheliferidae Risso, 1827

\section{Dactylochelifer latreillii (Leach, 1817)}

31: $22 \operatorname{Sep} 2013,1$ ふ.

Family Chernetidae Menge, 1855

\section{Chernes hahnii (C.L. Koch, 1839)}

7: 9 Sep 2014, 1 Tn; 12: 15 Aug 2012, 1 क; 8 Oct 2012, 1 q, 1 ふૈ; 18 Oct 2013, 1 Dn.

\section{Dinocheirus panzeri (C.L. Koch, 1837)}

1: 25 Oct 2013, 1 ․

\section{Allochernes wideri (C.L. Koch, 1843)}

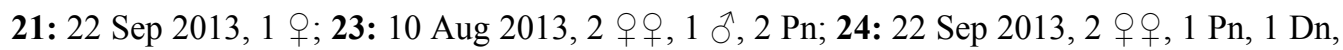
2 Tn; 29: 1 Sep 2013, 2 ふ઼.

\section{Lamprochernes spp.}

(Figs 2 \& 3)

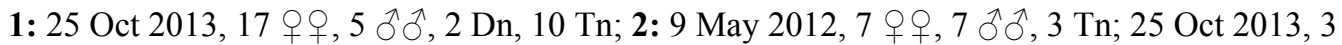

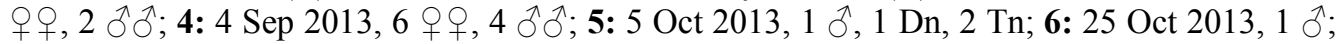

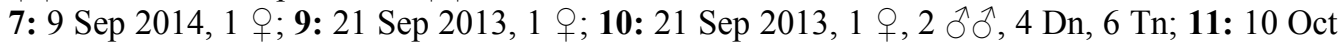

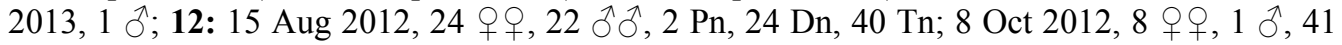
Pn, 40 Dn, 12 Tn; 18 Oct 2013, 2 우, 29 Dn, 30 Tn; 13: 21 Sep 2013, 2 q , 3 Dn, 5 Tn; 14:

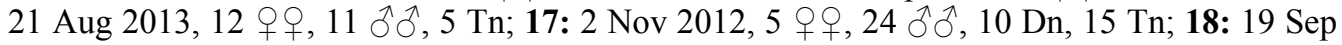

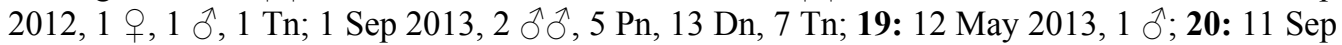
2013, 1 , 3 Dn, 4 Tn; 22: 19 Sep 2012, 2 우, 33 Pn, 23 Dn, 7 Tn; 23: 10 Aug 2013, 4 Pn, 2 Dn; 24: 22 Sep 2013, 1 Pn; 28: 26 Oct 2013, 6 우, 4 ठึ่; 30: 10 Oct 2013, 1 Tn; 31: 22 Sep 2013, 1 Pn; 32: 22 Sep 2013, 10 우, 12 $\widehat{\jmath}, 3$ Pn, 22 Dn, 47 Tn; 33: 7 Nov 2013, 1 ㅇ, 1. 


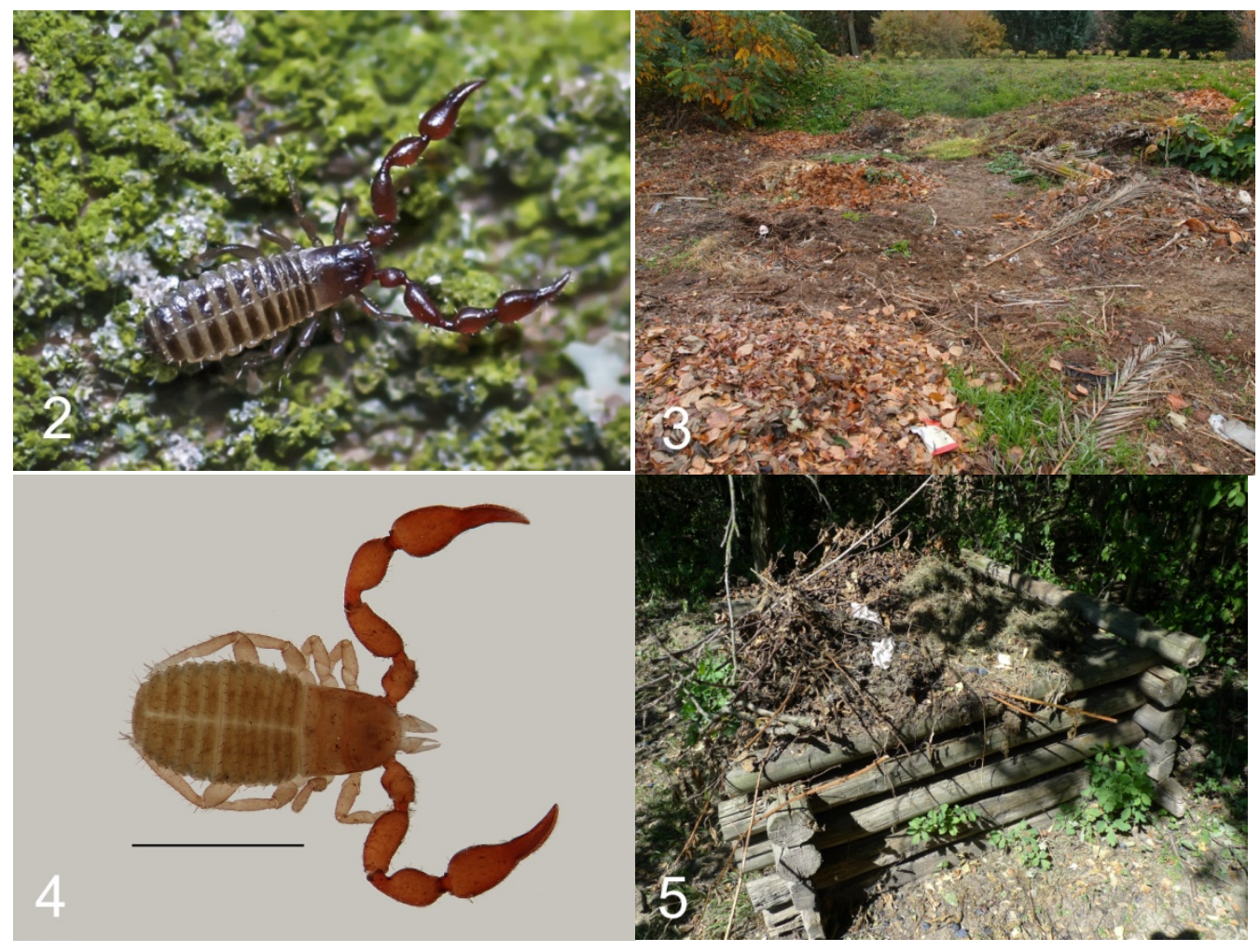

Figs 2-5. Pseudoscorpions and their habitat in heaps with decomposing material in Slovakia; 2 - Lamprochernes spp.; 3 - Compost heap in Botanical Garden, Bratislava; 4 - Pselaphochernes scorpioides, scale: 1 mm; 5 - Compost at Plevovec, Kopanice u Zlatých. Photo 2 by A. Šestáková, photos 3-5 by J. Christophoryová.

\section{Pselaphochernes scorpioides (Hermann, 1804)}

(Figs 4 \& 5)

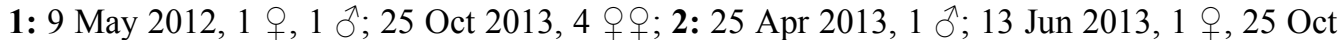

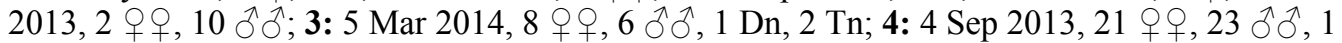
A, 15 Pn, 24 Dn, 12 Tn; 5: 5 Oct 2013, 3 우, 1 ภૈ; 9: 21 Sep 2013, 4 우, 3 ổ, 1 Tn; 12: 15

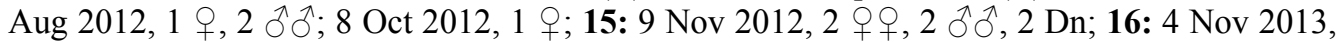

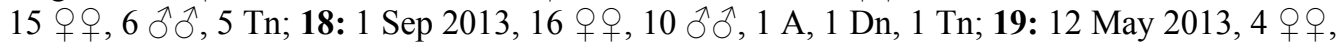

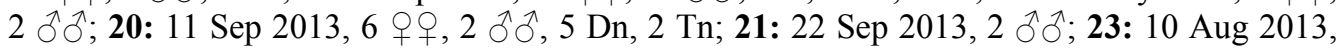

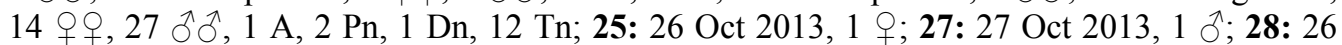

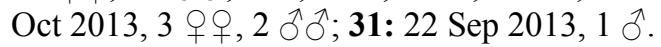

Nymphs were found for the majority of the species (Table 3). The presence of all nymphal stages was recorded mainly for Lamprochernes spp. and $P$. scorpioides (Table 3). Deutonymphs and tritonymphs were collected in chthoniid species (Table 3). Six females of $P$. scorpioides with eggs were found in compost heaps - one in May, one in June and four in September. Females of most species construct a brood nest, which explains why the females with eggs and, in some cases, protonymphs could not be extracted by Tullgren funnels. 
Table 3. Number of recorded nymphal stages of some pseudoscorpion taxa in compost heaps.

\begin{tabular}{|c|c|c|c|c|c|}
\hline \multirow{2}{*}{ No } & \multirow{2}{*}{ Taxa / } & \multicolumn{3}{|c|}{ Nymphal stages } & \multirow{2}{*}{$\sum$} \\
\hline & & Protonymphs & Deutonymphs & Tritonymphs & \\
\hline 1 & C. ressli & & 2 & 27 & 29 \\
\hline 2 & C. tetrachelatus & & 18 & 16 & 34 \\
\hline 3 & N. carcinoides & 4 & 2 & & 6 \\
\hline 4 & C. hahnii & & 1 & 1 & 2 \\
\hline 5 & A. wideri & 3 & 1 & 2 & 6 \\
\hline 6 & Lamprochernes spp. & 90 & 176 & 195 & 461 \\
\hline 7 & P. scorpioides & 17 & 34 & 35 & 86 \\
\hline & & 114 & 234 & 276 & 624 \\
\hline
\end{tabular}

Pseudoscorpions of the genus Lamprochernes were present in all distinguished categories (see Material and Methods). The other chernetid, P. scorpioides, was found in all categories except $\mathrm{C}$ and $\mathrm{F}$ (Table 4). Lamprochernes and $P$. scorpioides occurred simultaneously in one third of the collected samples (Table 2). The family Chthoniidae was most numerous in the forest environment. However, C. tetrachelatus was present almost in all environmental categories, except cow sheds and botanical gardens. Other species recorded during the study were present accidentally in the collected material (Table 4).

Table 4. Specimen number of pseudoscorpions in compost heaps according to environmental type listed in Table 1. For categories A - F see Material and Methods.

\begin{tabular}{|c|c|c|c|c|c|c|c|}
\hline \multirow{2}{*}{ No } & \multirow{2}{*}{ Taxa } & \multicolumn{6}{|c|}{ Environmental category } \\
\hline & & $\mathrm{A}$ & $\mathrm{B}$ & $\mathrm{C}$ & $\mathrm{D}$ & $\mathrm{E}$ & $\mathrm{F}$ \\
\hline 1 & C. ressli & & & & & 49 & \\
\hline 2 & C. fuscimanus & & 2 & & & & \\
\hline 3 & C. tetrachelatus & 26 & 11 & 8 & & 22 & \\
\hline 4 & N. carcinoides & 6 & 2 & & & & \\
\hline 5 & D. latreillii & & 1 & & & & \\
\hline 6 & C. hahnii & 4 & 1 & & & & \\
\hline 7 & D. panzeri & & & & 1 & & \\
\hline 8 & A. wideri & 8 & & & & 6 & \\
\hline 9 & Lamprochernes spp. & 549 & 14 & 38 & 57 & 13 & 2 \\
\hline 10 & P. scorpioides & 200 & 65 & & 20 & 13 & \\
\hline & 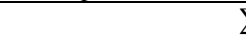 & 793 & 96 & 46 & 78 & 103 & 2 \\
\hline
\end{tabular}

\section{DISCUSSION}

During the study, 10 pseudoscorpion taxa were identified from heaps with decomposing material. Four species were recorded for the first time from compost heaps in Slovakia previously (Christophoryová 2009, Christophoryová et al. 2014), of which C. hungaricus and A. politus were not found during the present study.

Members of Chthoniidae and Neobisiidae usually live in leaf litter and the upper part of the soil. Three chthoniid species and one species of Neobisiidae were recorded from heaps with decomposing material during our study. The species $C$. ressli and $C$. tetrachelatus were collected in higher numbers mainly in the forest environment or in domestic gardens. Chthonius tetrachelatus, from the family Chthoniidae, was found in the highest number of samples. In Slovakia, it is the most common species of Chthoniidae (Christophoryová 2013). Mock et al. (2005) identified as Chthonius cf. ressli (earlier reported as $C$. aff. ressli by Mock et al. 2004) a single specimen collected from Klenbová Cave in Čierna hora Mts, Slovakia. Mock et al. (2004, 2005) noticed that this was probably the first record of this pseudoscorpion in Slovakia, but that it should be confirmed by more detailed study. Here we confirm the presence of $C$. ressli in Slovakia. This is a rare species, previously recorded only from a few 
localities in France, Italy, Austria, Hungary and the Czech Republic (Harvey 2013, Novák \& Kutasi 2014). The majority of findings in Italy were from mole nests (Inzaghi 1981), but elsewhere most records are from under stones or in caves (Beier 1956, 1963; Judson 1990; Mock et al. 2004, 2005; Št’áhlavský 2006; Novák \& Kutasi 2014). Previously, C. fuscimanus was recorded from Slovakia only in leaf litter and soil (Christophoryová 2013). Neobisium carcinoides is considered to be a eurytopic species (Beier 1963). In Slovakia, it is generally epigeic, but it was also collected from tree hollows, bird nests, dead wood, using Malaise traps and cardboard strips (Christophoryová 2010, 2013; Christophoryová et al. 2011a, 2014; Krajčovičová \& Christophoryová 2014). Ressl \& Beier (1958) recorded C. fuscimanus, C. tetrachelatus and $N$. carcinoides from compost heaps containing plant material and located near streams and forest edges in Austria.

During this study, only one specimen of each species Dactylochelifer latreillii and Dinocheirus panzeri was found. Ressl \& Beier (1958) recorded D. latreillii from forest compost containing plant material in Austria, and Drogla \& Lippold (2004) found it sporadically in compost in West Germany. One male of D. panzeri was collected in compost in the Czech Republic (Št'áhlavský \& Chytil 2013). Also in West Germany, this species was reported as frequently occurring in compost (Drogla \& Lippold 2004). The chernetids $C$. hahnii and A. wideri are commonly found under tree bark, in tree hollows, bird nests and in decaying wood, or collected using Malaise traps (Krumpál \& Christophoryová 2007; Christophoryová 2010; Christophoryová \& Krumpál 2010; Christophoryová et al. 2011a, 2014; Krajčovičová \& Christophoryová 2014). During this study, only a few specimens of both these species were recorded in heaps with decomposing material, containing mainly grass, plant and animal waste.

Most of the specimens collected from heaps with decomposing material belong to species of the genus Lamprochernes. They were present in heaps of all environmental categories and at almost all sampled localities. Besides, the Lamprochernes species were found in all developmental stages. At present, two Lamprochernes species (L. chyzeri and L. nodosus) are known from Slovakia (Christophoryová et al. 2012). The species L. chyzeri was described from localities in Slovakia by Tömösváry (1882). It was recorded mainly in Europe, but also in Georgia, Kazakhstan and Turkey (Harvey 2013). It was frequently recorded from natural habitats, particularly from under tree bark, bird nests and rarely from compost heaps (Beier 1963; Legg \& Jones 1988; Drogla \& Lippold 2004; Krumpál \& Christophoryová 2007; Christophoryová 2009, 2010; Christophoryová et al. 2012). Harvey (2013) noticed that L. nodosus was distributed in whole Europe, in Asia and Africa. It was more often associated with humans, lives in compost heaps and manure or, more rarely, in bird nests, under tree bark or sparophytic fungi (Beier 1963; Mašán \& Krištofík 1992; Krištofík et al. 1995, 1996; Drogla \& Lippold 2004; Christophoryová \& Krumpál 2010; Krajčovičová \& Christophoryová 2014). The identification of both species is based on questionable characters. According to the identification key in Legg \& Jones (1988) the female anterior genital operculum bears more than 20 setae in L. nodosus and 9-11 setae in L. chyzeri, but Christophoryová et al. (2011c) did not observe any specimens either of these species with less than 20 setae. The morphometric data on palps are overlapping (Christophoryová et al. 2011c). The main diagnostic character that differentiates both species from each other is the shape of protuberance on palpal trochanter, but this character is very subjective. Because of these facts we were unable to distinguish these two species by the morphological characters. The collected material is used in detailed molecular and taxonomic analysis. DNA extraction and sequencing fragments of the mitochondrial protein-encoding cytochrome c oxidase subunit gene (COI) of 20 adult specimens was conducted. The preliminary results confirm the occurrence of both species in Slovakia. At some localities (Bratislava, Botanical garden, Čataj and Nitra), both of the species 
were present simultaneously. The main diagnostic characters were checked and $30 \%$ of the sequenced specimens were incorrectly identified based on the shape of protuberance on palpal trochanter. None of the collected females bears less than 20 setae on anterior genital operculum and the measurements of palpal femur overlapped. Other specimens will be analysed and many continuous and discrete morphological characters will be measured and scored.

Pselaphochernes scorpioides occurred in heaps with decomposing material in almost all environmental categories and localities and was represented by all developmental stages, including females with eggs. This habitat type is favoured by $P$. scorpioides, as confirmed by findings in other European countries (Beier 1955, 1961, 1963, 1966; Ressl \& Beier 1958; Ress1 1970; Jędryczkowski 1985; Drogla \& Lippold 2004; Štáhlavský 2006). In Slovakia, it was collected in leaf litter, bird and ant nests, dead wood, tree hollows, decaying wood and under tree bark, as well as by using Malaise traps (Krumpál \& Christophoryová 2007; Christophoryová 2010, 2013; Christophoryová \& Krumpál 2010; Christophoryová et al. 2011a, 2014; Krajčovičová \& Christophoryová 2014; Jászayová et al. 2015).

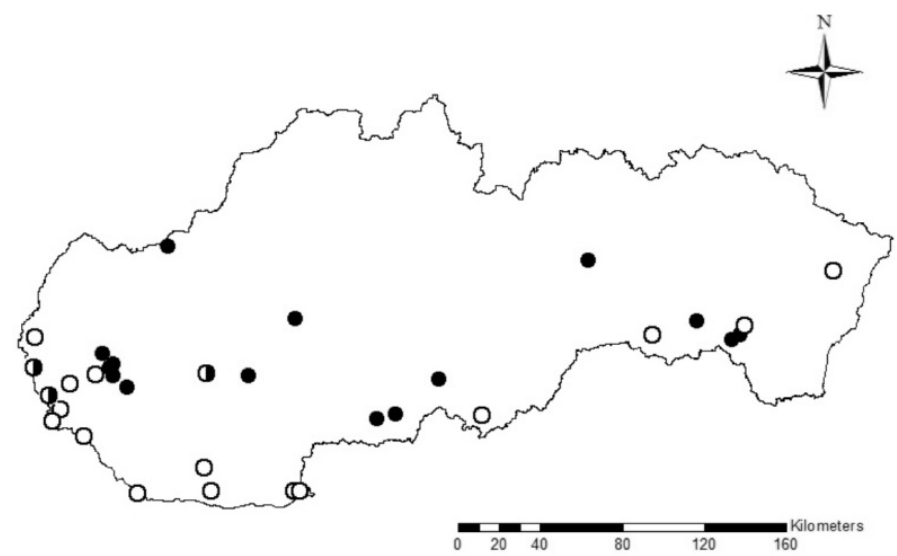

Fig. 6. Distribution of the genus Lamprochernes in Slovakia; white dots represent published data from different habitat types (Tömösváry 1882, Mašán \& Krištofík 1992, Krištofík et al. 1994, 1995, 1996, Krumpál et al. 1997, Krumpál \& Christophoryová 2007, Christophoryová 2009, 2010, Christophoryová \& Krumpál 2010, Christophoryová et al. 2011a, 2011b, 2014, Krajčovičová \& Christophoryová 2014); black dots represent current data from heaps with decomposing material; black-and-white dots represent intersections of the previously published locations with new data.

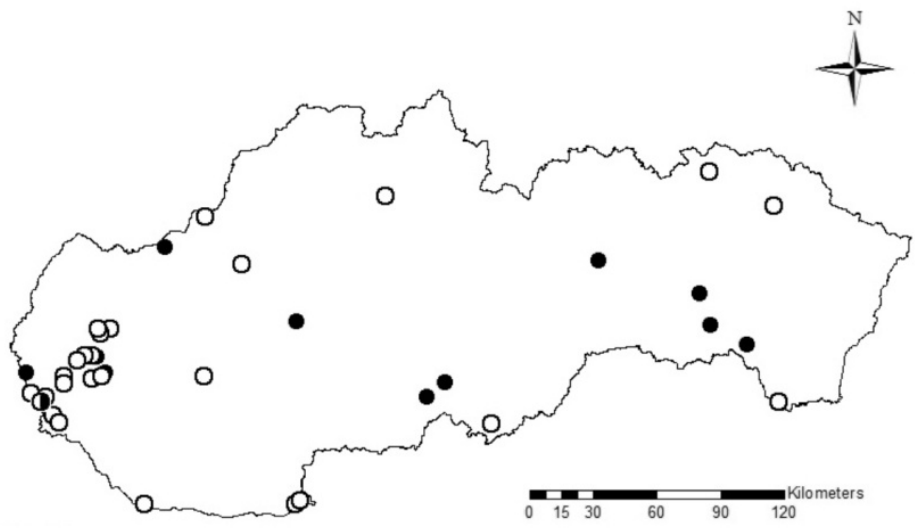

Fig. 7. Distribution of Pselaphochernes scorpioides in Slovakia; white dots represent published data from different habitat types (Krumpál \& Christophoryová 2007, Christophoryová \& Krumpál 2010, Christophoryová et al. 2011a, 2014, Christophoryová 2013, Krajčovičová \& Christophoryová 2014, Jászayová et al. 2015); other dots as in Figure 6. 
Lamprochernes spp. and $P$. scorpioides are typical inhabitants of heaps with decomposing material. Many new localities of these taxa we recorded in Slovakia during this study (Figs $6 \& 7$ ). Future research of the compost heaps and other accumulations of waste could lead to more records of pseudoscorpion that are rare or unknown in this country.

\section{ACKNOWLEDGEMENTS}

We are grateful to the other collectors listed in Material and Methods section for providing the pseudoscorpion material used in this paper. Special thanks go to Dr Giulio Gardini for checking and confirming the identification of chthoniid species and Dr Anna Šestáková for the Lamprochernes photo. We thank Alica Christophoryová and Erika Igondová for technical assistance with figures. The authors are grateful to the anonymous reviewers of the paper for helpful comments. This study was financed by the project VEGA 1/0191/15.

\section{REFERENCES}

BEIER M. 1955. Neue Beiträge zur Kenntnis der iberischen Pseudoscorpioniden-Fauna. Eos, Madrid 31: 87-122.

BEIER M. 1956. Bemerkenswerte Pseudoscorpioniden-Funde aus Niederösterreich. Entomologisches Nachrichtenblatt 8: $24-25$.

BEIER M. 1961. Pseudoscorpione von den Azoren und Madeira. Boletim do Museu Municipal do Funchal 14: 67-74.

BEIER M. 1963. Ordnung Pseudoscorpionidea (Afterskorpione). Bestimmungsbücher zur Bodenfauna Europas. Vol. 1.

Akademie-Verlag, Berlin. 313 pp.

BEIER M. 1966. Zoologische Aufsammlungen auf Kreta. Pseudoscorpionidea. Annalen des Naturhistorichen Museums in Wien 69: 343-346.

ChristophoryovÁ J. 2009. Štúriky - Pseudoscorpiones. In: MAŠÁN P. \& MiHÁL I. (eds), Pavúkovce Cerovej vrchoviny (Arachnida: Araneae, Pseudoscorpiones, Opiliones, Acari), pp. 125-135. Štátna ochrana prírody SR Banská Bystrica, Správa CHKO Cerová vrchovina Rimavská Sobota, Ústav zoológie SAV Bratislava, Ústav ekológie lesa SAV Zvolen. 311 pp.

CHRISTOPHORYOVÁ J. 2010. Št’úriky (Pseudoscorpiones) pod kôrou stromov, v dutinách a hniezdach na Slovensku. Folia faunistica Slovaca 15: 1-12.

CHRISTOPHORYOVÁ J. 2013. A faunistic study on the pseudoscorpions (Arachnida: Pseudoscorpiones) of oakhornbeam forests in SW Slovakia. Munis Entomology \& Zoology 8: 634-645.

Christophoryová J. \& KRUMPÁl M. 2010. Št’úriky (Pseudoscorpiones) PR Šúr. In: MAJZlan O. VidLičKa L. (eds), Príroda rezervácie Šúr, pp. 105-114. Ústav zoológie SAV, Bratislava. 410 pp.

ChristophoryovÁ J., KRUMPÁlovÁ Z., KRIŠTOFíK J. \& ORSZÁGHOVÁ Z. 2011a. Associations of pseudoscorpions with different type of bird nests. Biologia, Bratislava 66: 669-677.

Christophoryová J., Stloukalová V. \& Stloukal E. 2011b. First record of phoresy of pseudoscorpion Lamprochernes chyzeri in Slovakia (Pseudoscorpiones: Chernetidae). Folia faunistica Slovaca 16(3): 139-142.

Christophoryová J., ŠŤÁHLAVSKÝ F. \& FEDOR P. 2011c. An updated identification key to the pseudoscorpions (Arachnida: Pseudoscorpiones) of the Czech Republic and Slovakia. Zootaxa 2876: 35-48.

CHRISTOPHORYOVÁ J., ŠŤÁHLAVSKÝ F. \& KRAJČOVIČOVÁ K. 2014. Št'úriky (Arachnida, Pseudoscorpiones) pohoria Burda (NPR Kováčovské kopce). Folia faunistica Slovaca 19: 161-167.

Christophoryová J., ŠŤÁHLAVSKÝ F., KRUMPÁL M. \& FedOR P. 2012. Pseudoscorpiones of Czech Republic and Slovakia: An annotated and revised checklist (Arachnida: Pseudoscorpiones). North-Western Journal of Zoology 8: $1-21$.

Drogla R. \& LipPold K. 2004. Zur Kenntnis der Pseudoskorpion-Fauna von Ostdeutschland (Arachnida, Pseudoscorpiones). Arachnologische Mitteilungen 27/28: 1-54.

Harvey M. S. 2013. Pseudoscorpions of the World. Version 3.0. Western Australian Museum, Perth. Available at: http://museum.wa.gov.au/catalogues-beta/pseudoscorpions (7 Dec 2015).

INZAGHI S. 1981. Pseudoscorpioni raccolti dal Sig. M. Valle in nidi di Talpa europaea L. nella provincia di Bergamo con descrizione di una nuova specie del gen. Chthonius C. L. Koch. Bollettino della Società Entomologica Italiana 113: 67-73.

JÁSZAYOVÁ A., ChristophORYOVÁ J. \& JÁSZAY T. 2015. Št'úriky (Pseudoscorpiones) v hniezdach Formica polyctena v doline Mníchovského potoka v masíve Stebníckej Magury. Folia faunistica Slovaca 20: 27-30. 
JĘDRYCZKOWSKI W. B. 1985. Zaleszczotki (Pseudoscorpiones) Mazowsza. Fragmenta Faunistica Musei Zoologici Polonici 29: 77-83.

JudSON M. L. I. 1990. On the presence of Chthonius (C.) halberti Kew and Chthonius (C.) ressli Beier in France with remarks on the status of Kewochthonius Chamberlin and Neochthonius Chamberlin (Arachnida, Chelonethida, Chthoniidae). Bulletin du Muséum National d'Histoire Naturelle 11: 593-603.

KRAJČOVIČOVÁ K. \& ChristophORYOVÁ J. 2014. Faunistic survey of pseudoscorpions (Arachnida: Pseudoscorpiones) collected from trees and using Malaise traps in Slovakia and the Czech Republic. Klapalekiana 50: 167-180.

KRIŠTOFÍK J., MAŠÁN P. \& ŠUSTEK Z. 1996. Ectoparasites of bee-eater (Merops apiaster) and arthropods in its nests. Biologiar 51: 557-570.

KRIŠTOFÍK J., ŠUSTEK Z. \& GAJDOŠ P. 1994. Arthropods in the nests of the Sand Martin (Riparia riparia Linnaeus, 1758 ) in South Slovakia. Biologia, Bratislava 49: 683-690.

KRIŠTOFÍK J., ŠUSTEK Z. \& GAJDOŠ P. 1995. Arthropods in the penduline tit (Remiz pendulinus) nests: occurrence and abundance in different breeding phases. Biologia, Bratislava 50: 487-493.

KRUMPÁL M. \& ChristophoryovÁ J. 2007. Štúriky (Pseudoscorpiones) PR Ostrov Kopáč. In: MAJZlan O. (ed.), Príroda Ostrova Kopáč, pp. 95-100. Fytoterapia OZ, Bratislava. 287 pp.

KRUMPÁL M., KRUMPÁlovÁ Z. \& CYPRICH D. 1997. Bezstavovce (Evertebrata) skleníkov Bratislavy (Slovensko). Entomofauna carpathica 9: 102-106.

LEGG G. \& JonES R. E. 1988. Pseudoscorpions (Arthropoda, Arachnida). Key and notes for the identification of the species. In: KERMACK D. M. \& BARNES R. S. K. (eds), Synopses of the British Fauna (New Series). No. 40, pp. 1159. The Linnean Society of London and the Estuarine and Brackish-Water Sciences Association, Leiden - New York - København - Köln. 159 pp.

MAŠÁN P. \& KRIŠTOFíK J. 1992. Phoresy of some arachnids (Acarina and Pseudoscorpionidea) on synanthropic flies (Diptera) in the south Slovakia. Biologia, Bratislava 47: 87-96.

MOCK A., L'UPTÁČIK P., FENĎA P. \& PAPÁČ V. 2004. Biologická charakteristika jaskýň Bujanovských vrchov (Čierna hora). Aragonit 9: 35-40.

Mock A., ĹuptáčiK P., FenĎa P., SvatoŇ J., OrszÁgh I. \& KRuMPÁL M. 2005. Terrestrial arthropods inhabiting caves near Vel'ký Folkmar (Čierna hora Mts., Slovakia). In: TAJOvSKÝ K., SCHLAGHAMERSKÝ J. \& PIŽL V. (eds), Contributions to Soil Zoology in Central Europe I, pp. 95-101. Institute of Soil Biology, Academy of Sciences of the Czech Republic, České Budějovice. 221 pp.

NovÁK J. \& KUTASI C. S. 2014. New data on the Pseudoscorpion fauna of the caves of the Bakony Mountains, Hungary. Opuscula Zoologica 45: 189-194.

RESSL F. 1970. Weitere Pseudoskorpion-Funde aus dem bezirk Scheibbs (Niederösterreich). Berichte des Naturwissenschaftlich-Medizinischen Vereins in Innsbruck 58: 249-254.

RESSL F. \& BEIER M. 1958. Zur Ökologie, Biologie und Phänologie der heimischen Pseudoskorpione. Zoologische Jahrbücher, Abteilung für Systematik, Ökologie und Geographie der Tiere 86: 1-26.

ŠŤÁHLAVSKÝ F. 2006. Štírci (Arachnida: Pseudoscorpiones) Národního parku Podyjí. Klapalekiana 42: $167-178$.

ŠŤÁHLAVSKÝ F. \& CHYTIL J. 2013. Štírci (Arachnida: Pseudoscorpiones) Biosférické rezervace Dolní Morava a okolí (Česká republika). Klapalekiana 49: 73-88.

TÖMÖSVÁRY O. 1882. Pseudoscorpiones Faunae Hungaricae. A Magyar fauna álskorpiói. Magyar Tudományos Akadémia Matematikai és Természettudományi Közlemények 18: 135-256.

VERNER P. H. 1971. Štírci - Pseudoscorpionidea. In: DANIEL M. \& ČERNÝ V. (eds), Klíč zvířeny ČSSR. Díl IV, pp. 19-31. Československá akademie věd, Praha. 603 pp.

\section{STRESZCZENIE}

\section{[Zaleszczotki (Arachnida: Pseudoscorpiones) pryzm kompostowych na Słowacji]}

Celem badań było uzyskanie szerszych danych na temat zaleszczotków w pryzmach kompostowych. Materiał zbierano w latach 2012-2014 na 33 stanowiskach na Słowacji. Łącznie przeanalizowano 1118 osobników z 10 gatunków i 4 rodzin. Gatunki z rodzaju Lamprochernes były oznaczone tylko do rodzaju, ze względu na trudności w ich rozróżnieniu w oparciu o cechy morfologiczne. Najliczniej występujące zaleszczotki reprezentowały rodzinę Chernetidae, zaś najmniej gatunków należało do rodzin Neobisiidae i Cheliferidae - ich przedstawiciele występowali tylko sporadycznie. Najliczniej stwierdzone gatunki z rodziny Chernetidae to: Lamprochernes sp. oraz Pselaphochernes scorpioides. Z gatunków Dactylochelifer latreillii i Dinocheirus panzeri odnotowano tylko pojedyncze osobniki. W badanich potwierdzono występowanie na Słowacji rzadkiego gatunku Chthonius ressli. Ponadto wykazano, że Lamprochernes spp. i P. scorpioides są typowymi 
mieszkańcami pryzm kompostowych, gdzie przebiega ich cały cykl życiowy; tam znajdowano ich wszystkie stadia rozwojowe, a nawet samice z jajami ( $P$. scorpioides). Pryzmy kompostowe reprezentowały różne kategorie siedliska $\mathrm{z}$ uwagi na typ środowiska oraz etap rozkładu gnijącego materiału. Zaleszczotki z rodzaju Lamprochernes znaleziono w pryzmach należących do każdej z sześciu wyróżnionych kategorii. W pryzmach z czterech kategorii stwierdzono P. scorpioides. Rodzina Chthoniidae była odnotowywana najczęściej w kompoście leśnym. Gatunki spoza tej rodziny były znajdywane znacznie rzadziej, co wskazuje na ich zaledwie sporadyczną obecność w materiale kompostowym.

Accepted: 25 April 2016 